The Effect of Bicarbonate on the Microbial Dissolution of Autunite Mineral in the Presence of Gram-Positive Bacteria

Paola Sepulveda-Medina ${ }^{\mathrm{a}, \mathrm{b}}$, Yelena Katsenovich*a, Dawn Wellman ${ }^{\mathrm{c}}$, Leonel Lagos ${ }^{\mathrm{a}}$.

${ }^{\mathrm{a}}$ Applied Research Center and ${ }^{\mathrm{b}}$ Department of Biomedical Engineering, Florida International

University, 10555 W. Flagler Street, Miami, FL 33174, USA

${ }^{c}$ Pacific Northwest National Laboratory, PO Box 999, K3-62, Richland, WA 99352

*Corresponding author. E-mail: katsenov@ fiu.edu; phone: 305-348-2338; fax: (305)348-5018 


\section{The Effect of Bicarbonate on the Microbial Dissolution of Autunite Mineral in the Presence of Gram-Positive Bacteria} (1)

\section{Abstract}

Bacteria are key players in the processes that govern fate and transport of contaminants. The uranium release from $\mathrm{Na}$ and $\mathrm{Ca}$-autunite by Arthrobacter oxydans strain G968 was evaluated in the presence of bicarbonate ions. This bacterium was previously isolated from Hanford Site soil and in earlier prescreening tests demonstrated low tolerance to U(VI) toxicity compared to other A.oxydans isolates. Experiments were conducted using glass serum bottles as mixed bioreactors and sterile 6-well cell culture plates with inserts separating bacteria cells from mineral solids. Reactors containing phosphorus-limiting media were amended with bicarbonate ranging between 0-10 $\mathrm{mM}$ and meta- autunite solids to provide a U(VI) concentration of $4.4 \mathrm{mmol} / \mathrm{L}$. Results showed that in the presence of bicarbonate, A.oxydans G968 was able to enhance the release of $\mathrm{U}(\mathrm{VI})$ from $\mathrm{Na}$ and $\mathrm{Ca}$ autunite at the same capacity as other A.oxydans isolates with relatively high tolerance to U(VI). The effect of bacterial strains on autunite dissolution decreases as the concentration of bicarbonate increases. The results illustrate that direct interaction between the bacteria and the mineral is not necessary to result in $\mathrm{U}(\mathrm{VI})$ biorelease from autunite. The formation of secondary calcium-phosphate mineral phases on the surface of the mineral during the dissolution can ultimately reduce the natural autunite mineral contact area, which bacterial cells can access. This thereby reduces the concentration of uranium released into the solution. This study provides a better understanding of the interactions between meta-autunite and microbes in conditions mimicking arid and semiarid subsurface environments of western U.S. 
Keywords: Autunite mineral, Arthrobacter sp, aqueous bicarbonate, radionuclides, microscopy

1. Introduction

Uranium (VI) is a key contaminant of concern at many former U.S. Departments of Energy nuclear processing facilities and is well known as a health hazard for its toxicity and radioactivity. In neutral or basic $\mathrm{pH}$ conditions, uranium undergoes hydrolysis in aqueous solutions and can readily complex with a wide variety of ligands (Grenthe et al., 1992). Common ligands in the environment that form a diverse suite of aqueous uranyl complexes include: hydroxyl, phosphate, carbonate, silicate and organic substances (Lenhart et al., 2000; Davis, 2001). These complexation reactions often result in the formation of mobile aqueous species or precipitation of U-bearing minerals.

Soil properties, groundwater and pore water characteristics have a tremendous effect on uranium speciation and the formation of mineral phases (Sowder et al., 2001). Surveys of the uraniumcontaminated areas suggested that carbonate and hydrogen carbonate (known as bicarbonate) are the major ions in the groundwater composition and the pore water is saturated with $\mathrm{Ca}$ and $\mathrm{Mg}$ carbonates. Aqueous carbonate is considered one of the major variables affecting the dissolution of actinides from soil and sediments, thus increasing uranium mobility in natural waters (Clark et al., 1995; Zachara et al., 2007). In a bicarbonate-rich environment, carbonate anions are an important complexing agent for U(VI), forming highly soluble and stable uranyl dicarbonate $\mathrm{UO}_{2}\left(\mathrm{CO}_{3}\right)_{2}{ }^{2-}$ and uranyl tricarbonate $\mathrm{UO}_{2}\left(\mathrm{CO}_{3}\right)_{3}{ }^{4-}$ complexes, which became the predominant aqueous species at pH 7.0-8.0 (Langmuir, 1978; Bernhard et al., 2001; Guillaumont et al., 2003; Gorman-Lewis et al., 2008). In the presence of Ca ions, the mobile calcium uranyl carbonate species, $\mathrm{CaUO}_{2}\left(\mathrm{CO}_{3}\right)_{3}{ }^{2-}$, influence the speciation of uranium (Clark et al., 1995; Kalmykov and Choppin, 2000; Bernhard et al., 2001). 
Uranium readily forms strong and stable complexes with phosphate, promoting the formation of autunite group minerals, $\mathrm{X}_{3-\mathrm{n}}{ }^{(\mathrm{n})+}\left[\left(\mathrm{UO}_{2}\right)_{2}\left(\mathrm{PO}_{4}\right)_{2}\right] \cdot \mathrm{xH}_{2} \mathrm{O}$, that can persist under intense weathering conditions over a long period of time (Giammar D., 2001). One of the remediation strategies to mitigate the mobility of uranium contamination in the subsurface is an injection of sodium tripolyphosphate solutions in water-saturated sediments to form low solubility precipitates, autunite, $\mathrm{Na}\left[\left(\mathrm{UO}_{2}\right)\left(\mathrm{PO}_{4}\right)\right] \cdot 3 \mathrm{H}_{2} \mathrm{O}$ (Wellman et al., 2006; Wellman et al., 2007). The autunite mineral group is very diverse and permits the substitution of a wide range of cations and varying degrees of hydration (Burns, 1999). In a calcium-rich soil, typical for arid and semi-arid environments of the western U.S, rapid ion-exchange reactions promote the replacement of sodium for calcium and the formation of calcium-autunite, $\mathrm{Ca}\left[\left(\mathrm{UO}_{2}\right)(\mathrm{PO} 4)\right]_{2} \bullet 3\left(\mathrm{H}_{2} \mathrm{O}\right)$ (Burns, 1999). In these reactions, two sodium cations are exchanged for the calcium ion to maintain the charge balance of the structure; the exchange is also associated with an increase in waters of hydration (Wellman et al., 2005). The solubility constant of the calcium form of autunite, log $\mathrm{K}_{\mathrm{sp}}$, has been measured as -48.36 with $2 \sigma$ uncertainty values of \pm 0.03 (Gorman-Lewis et al., 2009). The associated solubility products are presented in eq. 1.

$$
\mathrm{Ca}\left(\mathrm{UO}_{2}\right)_{2}\left(\mathrm{PO}_{4}\right)_{2} \cdot 3 \mathrm{H}_{2} \mathrm{O}=3 \mathrm{H}_{2} \mathrm{O}+\mathrm{Ca}^{2+}+2 \mathrm{PO}_{4}{ }^{3-}+2 \mathrm{UO}_{2}{ }^{2+}
$$

Autunite is a phosphorus-containing mineral; bacteria can liberate phosphorus, meeting their nutrient requirements and causing $\mathrm{U}$ mobilization back into the environment as a result of a breakdown of the mineral structure (Smeaton et al., 2008). The presence of indigenous bacterial populations that rapidly adapt to environmental conditions in soil and sediment can strongly influence the stability of uranyl phosphate phases. These bacteria can affect the dissolution and $\mathrm{U}(\mathrm{VI})$ complexation reactions due to the secretion of protons, various ligands and organic acids in their immediate habitats. In addition, bacterial cell walls, proteins and lipids contain functional 
groups such as carboxyl and phosphate, which are able to bind with uranium and are ultimately capable of affecting U (VI) mobility in aqueous systems (Fredrickson et al., 2004; Beazly et al., 2007). Therefore, understanding the role of bacteria on the stability of uranyl phosphates minerals is very important.

A number of studies have been carried out with a variety of the bacterial species in relation to their interaction with radionuclides in groundwater (Lloyd and Renshaw, 2005; Nedelkova et al., 2007). As previously described, the significance of bacteria-uranium interactions has been illustrated by focusing on three Gram-positive Arthrobacter species isolated from Hanford Site, which is the former the United State plutonium producing facilities, located along the Columbia River in eastern Washington State (Katsenovich et al., 2012 b).

Arthrobacter is one of the most common groups of bacteria in soils and are found in large numbers in Hanford soil as well as other subsurface environments contaminated with radionuclides (Balkwill et al., 1997; Boylen, 1973; Van Waasbergen et al., 2000; Crocker et al., 2000). According to Balkwill et al., (1997), the microbial ecology of vadose zone sediments contaminated with high $\mathrm{U}(\mathrm{VI})$ at the U.S. DOE Hanford Site exhibits a high frequency of Arthrobacter species. In addition, Arthrobacter-like bacteria were the most prevalent in the highly radioactive sediment samples collected underneath leaking high-level waste storage tanks and accounted for about one-third of the total isolatable bacterial population from vadose zone soils (Fredrickson et al., 2004). Furthermore, a prior study conducted using the A.oxydans strain G975 illustrated a bio-enhanced release of $\mathrm{U}(\mathrm{VI})$ from natural Ca-autunite in the presence of various concentrations of bicarbonate (Katsenovich et al., 2012a). The current research was performed to investigate the effect of Arthrobacter oxydans strain G968 obtained from the SMCC on stability of the autunite mineral in carbonate-rich oxidized conditions typical for the 
western U.S. This strain was found to possess low resistance to U(VI) toxicity in bicarbonatefree media solutions (Sepúlveda et al., 2013).

The microbial effect of strains that possess low tolerance to U(VI) toxicity on the dissolution of $\mathrm{U}(\mathrm{VI})$-bearing minerals have not been evaluated in publications. Additional research is necessary to understand the effect of bacterial cells with low resistance to U(VI) on the biodissolution of autunite in bicarbonate-amended media solutions mimicking subsurface conditions typical for arid and semi-arid environments of the western U.S. The objective of this research was (i) to evaluate the microbial dissolution of $\mathrm{Na}$ and $\mathrm{Ca}$ autunite in bicarbonate-amended solutions inoculated with Arthrobacter oxydans strain G968, that possesses a low tolerance to U(VI) toxicity, (ii) to compare the results of autunite dissolution with data obtained in previous tests using uranium- resistant subsurface isolate Arthrobacter oxydans strain G975, and (iii) to determine whether bacterial tolerance to uranium can affect autunite biodissolution in the presence of bicarbonate.

\section{Materials and Methods}

\subsection{Arthrobacter Strains and Culture Conditions}

Environmental sources and isolation of the Gram-positive aerobic Arthrobacter oxydans strain G968 used for the research was described in recent publications (Katsenovich et al., 2012a; Katsenovich et al., 2012 b). Identification of the A. oxydans strains was previously confirmed by 16S rDNA phylogeny (Balkwill et al., 1997; Van Waasbergen et al., 2000) and detailed descriptions of sample collection procedures and methods of bacterial isolation are available from Van Waasbergen et al. (2000). The bacterial culture was grown in 5\% peptone, tryptone, yeast extract, glucose (PTYG) liquid culture media and agar plates consisting of $5 \mathrm{~g} / \mathrm{L}$ peptone, 5 
$\mathrm{g} / \mathrm{L}$ tryptone, $10 \mathrm{~g} / \mathrm{L}$ yeast extract, $10 \mathrm{~g} / \mathrm{L}$ glucose, $0.6 \mathrm{~g} / \mathrm{L} \mathrm{MgSO}_{4} .7 \mathrm{H}_{2} \mathrm{O}$, and $0.07 \mathrm{~g} / \mathrm{L}$ $\mathrm{CaCl}_{2} \cdot 2 \mathrm{H}_{2} \mathrm{O}$. The media was prepared in deionized water (DIW) (Barnstead NANOpure Diamond Life Science (UV/UF), Thermo Scientific), autoclaved at $121^{\circ} \mathrm{C}$ and 15 psi for 15 minutes, then allowed to cool before being used. Bacterial cells were harvested in the late logarithmic phase of growth and washed; the cell stock suspensions were counted using a glass hemocytometer (Fisher Scientific, Pittsburg, PA) or INCYTO C-Chip disposable hemocytometer (SKC America). Once the average cell count was obtained, it was multiplied by the dilution factor and the volume factor $\left(10^{4}\right)$ in order to calculate the final concentration of cells per $\mathrm{mL}$. The number of cells/mL in the stock suspension was used to calculate the desired volume of cell solution to inoculate the experimental bottles.

To account for viable bacteria, a well-mixed homogeneous aliquot $(0.01 \mathrm{~mL}-0.1 \mathrm{~mL})$ of the suspension from each test vial was uniformly spread on the sterile Petri dishes containing a 5\% PTYG growth media mixed with $15 \mathrm{~g} / \mathrm{L}$ of agar. Inoculated plates were kept inverted in an incubator at $29^{\circ} \mathrm{C}$. Viable microorganisms were calculated from the number of colony-forming units (CFU) found on a specific dilution. In addition, the agar plating was used to provide a quick visual check for contamination and to maintain colonies from each stage of the enrichment for the duration of the experiment.

\subsection{Uranium (VI) release from Autunite mineral}

Two different kinds of bioreactors were used in the bioleaching experiments: (1) Sterile $100 \mathrm{~mL}$ serum bottles were used as mixed bioreactors for initial experimentation. These autunitecontaining bioreactors were inoculated with the desired volume of bacterial cell solution after the autunite equilibrated with the bicarbonate-amended media solutions and the dissolution of autunite was close to its solubility. 
Falcon $^{\mathrm{TM}}$ ) were used to keep bacteria and autunite separated during non-contact dissolution experiments.

\subsubsection{Bicarbonate Media Solution Preparation}

Autunite dissolution experiments were performed in a medium that was similar to the growth media, but did not contain yeast extract due to its high phosphorus content. The media was prepared in deionized water (DIW) (Barnstead NANOpure Diamond Life Science (UV/UF), Thermo Scientific), autoclaved at $121^{\circ} \mathrm{C}, 15$ psi for 15 minutes, and cooled to about $30^{\circ} \mathrm{C}$. After sterilization, the media was equally distributed between four $200-\mathrm{mL}$ bottles and separately amended to contain $0 \mathrm{mM}, 3 \mathrm{mM}, 5 \mathrm{mM}$, and $10 \mathrm{mM}$ of $\mathrm{KHCO}_{3}$. Potassium bicarbonate was used to prevent interference with $\mathrm{Na}$ measurements released from $\mathrm{Na}$-autunite during dissolution of the mineral. The media to conduct the autunite dissolution experiments was adjusted to $\mathrm{pH} 7.5$ with $0.1 \mathrm{M} \mathrm{HCl}$ or $\mathrm{NaOH}$ and buffered with $0.02 \mathrm{M}$ 2-(2-hydroxyethyl)-1-piperazine ethanesulfonic acid sodium salt hydrate (HEPES-Na) buffer. At this $\mathrm{pH}$, the major fraction of dissolved inorganic carbon is present in the form of $\mathrm{HCO}_{3}$. Each of the four individual bicarbonate media solutions were filter-sterilized $(0.2 \mu \mathrm{m})$ and kept refrigerated until the time of use.

\subsubsection{Autunite biodissolution in mixed bioreactors}

Natural Ca meta-autunite, $\mathrm{Ca}\left[\left(\mathrm{UO}_{2}\right)\left(\mathrm{PO}_{4}\right)\right]_{2} \cdot 3 \mathrm{H}_{2} \mathrm{O}$ obtained from Excalibur Mineral Corporation (Peekskill, New York), was previously characterized using ICP-OES, ICP-MS analyses, X-ray diffraction and SEM/EDS to confirm the mineral composition, structure, and morphology as 9899\% pure autunite (Wellman et al., 2006). The autunite sample was powdered and sieved to have a size fraction of 75 to $150 \mu \mathrm{m}$ or -100 to +200 mesh with a surface area of $0.88 \mathrm{~m}^{2} / \mathrm{g}$ as determined by $\mathrm{Kr}$-adsorption BET analysis (Wellman et al., 2006). 
Synthesis of Na-autunite, $\mathrm{Na}\left[\left(\mathrm{UO}_{2}\right)\left(\mathrm{PO}_{4}\right)\right] \cdot 3 \mathrm{H}_{2} \mathrm{O}$, was followed by a modified direct precipitation method described by several authors (Wellman et al., 2005, Gudavalli et al., 2013a).

In order to test if there is a difference in the microbial dissolution of synthetic and natural autunite in the presence of bicarbonate, a biodissolution experiment in two different kinds of bioreactors was conducted. Synthetic and natural autunite microbial biodissolution experiments were conducted similarly using $100-\mathrm{mL}$ foam-stoppered serum bottles prepared in triplicate for each bicarbonate concentration tested. Each bottle contained $50 \mathrm{~mL}$ of sterile bicarbonatebearing media buffered with $20 \mathrm{mM}$ HEPES-Na and $91 \mathrm{mg}$ of meta- autunite to provide a U(VI) concentration of $4.4 \mathrm{mmol} / \mathrm{L}$. This concentration was used to compare results with previous data obtained in the dissolution experiments using a U-tolerant Arthrobacter strain G975 (Katsenovich et al., 2012a). The suspensions were slightly agitated at 60-rpm in an incubator/shaker at $25^{\circ} \mathrm{C}$. Autunite and bicarbonate solutions were allowed to equilibrate with the solution to the point where the concentration of uranium reaches a plateau. Arthrobacter strain G968 cells at a cell density of $10^{6}$ cells $/ \mathrm{mL}$ were injected into the reactors after 27 days. A similar experimental approach to investigate biodissolution of U-bearing minerals in the presence of a dissimilatory metal-reducing bacterium (DMRB), Shewanella oneidensis, was discussed by Liu et al., (2006). Abiotic non-carbonate controls were used during testing. After addition of bacteria, the experiment was continued for 20 days.

\subsubsection{Autunite biodissolution in culture ware with inserts}

To investigate whether direct contact between the bacteria and the mineral was necessary to result in uranium release from the mineral, a bioleaching experiment in culture ware with inserts was performed. Sterile 6-well cell culture plates with inserts (BD Falcon ${ }^{\mathrm{TM}}$ ) were used in the 
non-contact biodissolution experiments where natural Ca-meta-autunite and bacterial cells were incubated separately. The culture plates inserts have $0.4 \mu \mathrm{m}$ cylindrical pores that transverse the permeable membrane and only allow the diffusion of small molecules, including soluble uranium and metabolites from Arthrobacter strain G968. Ten (10) mg of autunite powder was weighed on paper discs, covered with aluminum foil and then autoclaved at $121^{\circ} \mathrm{C}$ and 15 psi for 15 minutes. The sterile paper discs with autunite were carefully inserted with a pincette on the bottom of the wells and then insert receptacles were positioned in each corresponding well. Subsequently, the wells were filled with a sterile bicarbonate media solution prepared to be similar to those made for the serum bottle reactors to provide a U(VI) concentration of $4.4 \mathrm{mmol} / \mathrm{L}$ (Katsenovich et al., 2012 a). The total volume of the sterile media solution added to each individual well nested with a culture insert receptacle was $5.7 \mathrm{~mL}$. Only the well inserts equipped with $0.45 \mu \mathrm{m}$ pore size membranes were inoculated with $10^{6}$ cells $/ \mathrm{mL}$; this allowed culturing bacterial cells separately from autunite solids. Abiotic controls were prepared to make a comparison with bacteria-bearing wells. Uranium release from autunite was established by taking a $20 \mu \mathrm{L}$ sample from the inserts and processing on the kinetic phosphorescence analyzer (KPA), as described in greater detail in the next section. The solution volume withdrawn from each well was less than $2.5 \%$ of the total solution volume during the entire experiment.

\subsubsection{Analytical procedures}

Before bacteria inoculation, samples were taken twice a week; after inoculation, samples were taken daily. A $0.3 \mathrm{~mL}$ sample of the solution was aseptically withdrawn from each bottle, filtered $(0.2 \mu \mathrm{m})$, and then analyzed for dissolved U(VI) by means of a kinetic phosphorescence analyzer KPA-11 (Chemcheck Instruments, Richland, WA). The total solution volume removed from each bottle was less than $5 \mathrm{~mL}$ ( $<10 \%$ of total solution volume) during the entire experiment. 
The dilution factors for analysis were 100x for samples prepared with low concentrations of bicarbonate (0-3 mM), and 200x for samples prepared with higher concentrations of bicarbonate (5-10 $\mathrm{mM})$. Prior to this analysis, sample aliquots were ashed on a hot plate with the addition of concentrated plasma grade nitric acid and hydrogen peroxide solutions (Gudavalli et al., 2013b). Wet digestion was continued until a dry white precipitate formed, and then dry ashing was performed in the furnace at $450^{\circ} \mathrm{C}$ for $15 \mathrm{~min}$. Samples were allowed to cool at room temperature followed by the dissolution of the precipitate by the addition of $1 \mathrm{M}$ nitric acid $\left(\mathrm{HNO}_{3}\right)$. Aqueous concentrations of sodium, calcium and phosphorus were determined from the digested samples by means of an Optima 7300 ICP-OES (Perkin Elmer). Uranium calibration standards (SPEX certiPrep), blanks and check standards (95-105\% recovery) were analyzed for quality control. To examine the results that have numerous experimental groups and independent factors, such as studying the effect of U(VI) uptake due to varying concentrations of uranium (VI) in the presence of bicarbonate ions, ANOVA statistics were used. All statistical tests were investigated using a predictive analytical software, SPSS (IBM, Armonk, NY), with significant levels set at $\alpha=0.05$.

\subsubsection{SEM/EDS Analysis of samples}

The purpose of scanning electron microscopy with energy-dispersive X-ray spectroscopy (SEM/EDS) analysis was to characterize the microstructure of autunite solid phases and bacterial cell surface composition in the presence of bicarbonate. To prepare the samples for SEM imaging, a dehydration process was followed using a sample preservation protocol from Fratesi, et al., (2004) and Araujo, et al. (2003). At the end of the experiment samples from bioreactors were transferred to a centrifuge tube and washed twice with deionized water after centrifugation at $4000 \mathrm{rpm}$ for $5 \mathrm{~min}$. Bacteria in the samples were then fixed by treatment with $2 \%$ 
glutaraldehyde in 0.1M HEPES buffer at $\mathrm{pH} 7.2$ for $2 \mathrm{~h}$ at $4^{\circ} \mathrm{C}$ and subsequently dehydrated in ethanol/water solutions of 35\% (v/v), 70\% (v/v), and 90\% (v/v) each for $10 \mathrm{~min}$, and two times in $100 \%(\mathrm{v} / \mathrm{v})$ for $10 \mathrm{~min}$. Dehydrated samples were immersed for $10 \mathrm{~min}$ each in $50 \%$ and $100 \%$ pure hexamethyldisilazane (HMDS) (Pierce Biotechnology, Inc, obtained from Fisher Scientific) followed by 10 min of air-drying to allow liquid to evaporate from a sample. The dehydrated specimens were then kept in the desiccators until the time of SEM/EDS analysis. The dehydrated specimens were mounted on the SEM mounting plates with double sided sticky carbon tape and then coated for one minute with a thin layer of gold to increase conductivity. The microstructure of gold-coated samples (PAC-1 PELCO Advanced coater 9500) was analyzed using a SEMEnergy-Dispersive-Spectrometry (SEM-EDS) JEOL System Model 5900LV at $15 \mathrm{kV}$. The elemental composition was determined via a Noran System Six Model 200SEM Energy Dispersive X-Ray Spectroscopy (EDS).

\section{Results and Discussion}

\subsection{Release of $U(V I)$ from Natural Autunite}

The release of aqueous U (VI) over time during the autunite dissolution experiments is presented in Figure 1A, the red arrow indicates when the bioreactors were inoculated with A. oxygans strain G968. U(VI) concentrations in the abiotic control (a sample that did not contain bicarbonate or bacteria) reached a steady state over a period of 27 days with an average value of $0.46 \pm 0.11 \mu \mathrm{M}$. In bicarbonate-amended reactors, $\mathrm{U}(\mathrm{VI})$ release from autunite was strongly enhanced. Prior to strain inoculation, U(VI) concentrations were measured at $0.55 \pm 0.12 \mu \mathrm{M}$,

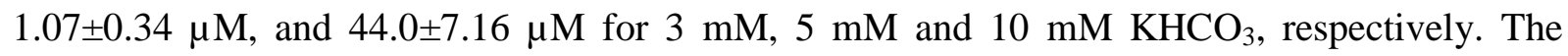
steady state maximum concentrations of $\mathrm{U}(\mathrm{VI})$ detected were $1.92,14.4,30.1$, and 44.4 fold higher than the control containing no bicarbonate and no bacteria. Furthermore, after bacterial 
inoculation, $\mathrm{U}(\mathrm{VI})$ concentrations measured in the reactors increased $3.0 \pm 4.16,23.3 \pm 13.8$, $19.0 \pm 28.0$, and $2.00 \pm 2.66$ fold, respectively, compared to the corresponding bicarbonatebearing controls at steady state. Statistical analysis indicated very strong evidence that the mean uranium values are dissimilar across the different groups of bicarbonate concentration $(\mathrm{P}<0.05)$. Even though there is an increased amount of U(VI) released out into the solution driven by the presence of bacteria, the effect of bacteria on autunite dissolution is reduced as the concentration of $\left[\mathrm{HCO}_{3}{ }^{-}\right]$increases. Since the steady-state $\mathrm{U}(\mathrm{VI})$ concentration is higher for larger $\left[\mathrm{HCO}_{3}{ }^{-}\right]$, the increase in soluble U(VI) concentration induced by bacteria is hindered. This was expected since the uranium release from autunite is strongly influenced by the increase in bicarbonate concentrations leading to the formation of aqueous uranyl bicarbonate complexes (Gudavalli et al, 2013a, 2013b). It was previously determined that uranium release from autunite minerals is a surface-mediated reaction with the uranium polyhedrons (Wellman et al., 2006; 2007). Bicarbonate can promote mineral dissolution by fast binding to the autunite surface, followed by slow detachment of the U(VI) carbonate species from the surface into solution (Sparks, 1999; Gudavalli et al, 2013a). The formation constants of these ternary uranyl carbonate complexes are higher than for the complexes built between uranyl ion and bacterial surface components (Gorman - Lewis et al. 2005; Haas et al. 2001). Results showed that the steady-state U(VI) concentration increases as a function of increasing bicarbonate, but the increase in soluble U(VI) concentration induced by bacteria is minimized in comparison. Therefore, as $\left[\mathrm{HCO}_{3}^{-}\right]$increases, a diminishing trend on the effect of bacteria on autunite dissolution was observed; a similar effect was reported in the autunite dissolution experiments using the A.G975 strain (Katsenovich et al, 2102a). 
The liberation of uranyl ions influences incongruent reactions to release phosphorus and sodium from autunite. Figure 1B illustrates the aqueous phosphorus release as a function of time from the natural autunite dissolution experiments inoculated with Arthrobacter strain G968. This figure also shows results for two controls, an abiotic control that contains no bicarbonate and no bacteria, and a biotic control, containing bacteria with no bicarbonate. During the autunite dissolution period without bacteria, phosphorus $(\mathrm{P})$ concentrations increased compared to the non-carbonate abiotic control. After inoculation, $\mathrm{P}$ concentrations in the biotic reactors were found to decrease for all studied bicarbonate concentrations. This was correlated with the exponential growth phase of bacteria that were seeded into the reactors. $\mathrm{P}$ is one of the major essential macronutrients for biological growth, playing a central role in the cellular activities for the synthesis of DNA, ATP, polyphosphates, and cell wall phospholipids. Within 5 days after inoculation, the total bacterial density showed a significant increase to $\log 8.77 \mathrm{cell} / \mathrm{mL}$ and $\log$ 8.94cell/mL for the bicarbonate-free and reactors amended with $10 \mathrm{mM}$ of $\mathrm{HCO}_{3}$, respectively. The viability of cells was slightly higher for the bicarbonate-amended reactors, 92-99\%, compared to bicarbonate-free reactors with values ranging between $86.5-94 \%$. It is known that microorganisms are capable of solubilising phosphate by accessing insoluble phosphate-bearing minerals through microbial dissolution (Vazques, et al. 2000; Goldstein, 1986). The primary mechanisms of $\mathrm{P}$ solubilization are $\mathrm{H}^{+}$excretion, production of low molecular weight organic acid, and acid phosphatase biosynthesis (Arcand and Schneider, 2006; Behera et al, 2014). As microbial growth consumes phosphorus as a nutrient, there is also likely a reduction in soluble $\mathrm{P}$ content in the media solution caused by the formation of insoluble secondary calcium phosphate phases (Figure 1B). Their formation was predicted by speciation modeling via Visual MINTEQ software [v.3.0, maintained by J.Gustafsson at KTH, Sweden, available at 
http://www.lwr.kth.se/English/OurSoftware/vminteq/ updated with the Nuclear Energy Agency's thermodynamic database for uranium (Guillaumont et al. 2003)] (Table 1). The calcium phosphate phases precipitated from the media solution and accumulated in the batch reactors. After bacteria inoculation, the average concentration of phosphorus in the solutions were measured as $4.3 \pm 0.66 \mathrm{mM}, 7.19 \pm 1.75 \mathrm{mM}, 6.74 \pm 0.85 \mathrm{mM}$, and $8.57 \pm 0.92 \mathrm{mM}$ for the tested 0 $\mathrm{mM}, 3 \mathrm{mM}, 5 \mathrm{mM}$ and $10 \mathrm{mM}$, respectively. Similar to phosphorus, aqueous Ca release over the period of autunite dissolution without bacteria was noted to increase as a function of bicarbonate concentrations (Figure 1C). Ca concentrations after bacterial inoculation averaged $2.8 \pm 0.6 \mathrm{mM}$, $2.99 \pm 1.16 \mathrm{mM}, 3.01 \pm 0.24 \mathrm{mM}$, and $3.34 \pm 0.34 \mathrm{mM}$ for the tested bicarbonate concentrations, respectively. The data indicate that release of $\mathrm{U}, \mathrm{P}$ and $\mathrm{Ca}$ from Ca-autunite was nonstoichiometric.

The Arthrobacter species has the potential of becoming an important component in the dissolution process. Their activities can contribute to the release of uranium via the dissolution of autunite minerals and might result in the formation of secondary calcium phosphate (apatite) phases. The high stability of uranyl-phosphate complexes makes them a strong candidate for the remediation efforts to sequester $\mathrm{U}$ in the subsurface. However, in a bicarbonate-rich oligotrophic environment typical for the western U.S., the Ca-autunite mineral has a high liability to dissolution in the presence of bacteria.

\subsubsection{U(VI) Release from Natural Autunite Mineral in Sterile Culture Plates with Inserts}

Dissolution experiments in which the natural autunite mineral was separated from the bacteria were conducted using sterile culture plates with inserts. The release of aqueous U (VI) over time in non-contact mode is represented in Figure 2. The steady state maximum concentrations of $U$ (VI) detected were 3.57, 1.34, and 1.41 fold higher than the abiotic control without the 
bicarbonate amendment. Furthermore, after bacterial inoculation, U (VI) concentrations measured in the reactors increased $3.96 \pm 1.17,2.79 \pm 1.62$, and $2.82 \pm 3.75$ fold for $0 \mathrm{mM}, 3 \mathrm{mM}$, and $5 \mathrm{mM}$ bicarbonate, respectively.

There is a slight increase in the release of uranium as bicarbonate increases; however, this is not as pronounced when compared to the biodissolution experiment in mixed reactors, where bacteria and mineral have direct contact. Statistical analysis indicated strong evidence that the means of uranium concentrations varied among different levels of bicarbonate concentrations $(\mathrm{P}<0.05)$. These measures were not optimum conditions for bacterial growth and proliferation. However, results do illustrate that direct interaction between the bacteria and mineral is not necessary to result in $\mathrm{U}(\mathrm{VI})$ release from autunite. It was not measured but it is likely that the release of $U$ from autunite in the non-contact experiments was affected by the organic substances produced by bacteria during aerobic metabolism.

\subsubsection{U (VI) Release from Synthetic Autunite}

The release of aqueous U(VI) over time during the synthetic autunite dissolution experiment is presented in Figure 3A. The bioreactors were inoculated with Arthrobacter strain G968 cells after 27 days, giving time for the synthetic autunite to reach steady state with the bicarbonate solutions. The steady state maximum concentrations of U(VI) detected were $2.09,8.83,52.3$, and 88.4 fold higher than the abiotic control without the bicarbonate amendment. This correlates with the observed increase in the uranium with the rising concentration of bicarbonate solutions, which is explained by the increase of the $\mathrm{CO}_{3}{ }^{2-}$ species in aqueous solutions and the formation of strong and highly soluble U(VI)-carbonate complexes (Gudavalli et al. 2013a). Furthermore, after bacterial inoculation, $\mathrm{U}(\mathrm{VI})$ concentrations measured in the reactors increased $1.13 \pm 0.47$, $2.51 \pm 0.53,1.65 \pm 1.45$, and $1.00 \pm 1.82$ fold for $0 \mathrm{mM}, 3 \mathrm{mM}, 5 \mathrm{mM}$ and $10 \mathrm{mM} \mathrm{KHCO}_{3}$, 
respectively. Statistical analysis suggests strong evidence that the mean of uranium concentrations are different among varying concentrations of bicarbonate $(\mathrm{p}<0.05)$. From Figure $3 \mathrm{~A}$, it can be inferred that the effect of bacteria on the synthetic autunite dissolution is reduced as the concentration of bicarbonate increases, despite the increased amount of U(VI) leached in the solution. Similar to previous experimentation conducted with $\mathrm{Ca}$-autunite, as $\left[\mathrm{HCO}_{3}{ }^{-}\right]$increases, a diminishing trend on the effect of bacteria on autunite leaching was observed; however, in this case detected U(VI) concentrations were slightly higher.

Phosphorus $(\mathrm{P})$ concentrations in the biotic reactors were found to increase slightly for all studied bicarbonate concentrations (Figure 3B). After bacteria inoculation, the average concentrations of phosphorus in the supernatant solutions were measured as $1.55 \pm 0.29 \mathrm{mM}$, $1.51 \pm 0.24 \mathrm{mM}, 1.72 \pm 0.25 \mathrm{mM}, 2.04 \pm 0.18 \mathrm{mM}$ for the tested $0 \mathrm{mM}, 3 \mathrm{mM}, 5 \mathrm{mM}$ and $10 \mathrm{mM}$, respectively. As suggested by speciation modeling, the dissolution of synthetic Na-autunite doesn't result in the formation of phosphorus-bearing solid phases, and $\mathrm{HPO}_{4}{ }^{-2}$ anions remain in the media solution. Similar to phosphorus concentrations, after bacterial inoculation, sodium concentrations in the biotic reactors were found to increase for all studied bicarbonate concentrations (Figure 3C). Sodium concentrations in the bioreactor followed a similar trend compared to $\mathrm{U}(\mathrm{VI})$ and phosphorus concentrations and, by the end of the experiments, increased in average about $10 \%$ compared to pre-inoculation levels. Data indicate that the release of elements from synthetic autunite is not stoichiometric.

\subsubsection{Comparing Biodissolution of Natural autunite with Synthetic autunite}

One of the objectives of the study was to investigate if Arthrobacter strain G968 influences uranium release through biodissolution. There is a question, however, if there was a difference between the microbial effect on the dissolution of synthetic autunite and natural autunite in the 
presence of bicarbonate. A previous study comparing the kinetic rate law parameters for abiotic dissolution of natural and synthetic autunite in the presence of bicarbonate solutions (Gudavalli et al., 2013b) concluded that the uranium release from natural autunite is higher than from synthetic autunite. Major factors that contribute to a higher uranium release from natural autunite are the formation of uranyl-carbonate, $\mathrm{UO}_{2}\left(\mathrm{CO}_{3}\right)_{3}{ }^{4-}$, and calcium-uranyl-carbonate species, $\mathrm{CaUO}_{2}\left(\mathrm{CO}_{3}\right)_{3}{ }^{2-}$. These complexes act as a driving force for uranyl release from mineral surfaces. Furthermore, natural autunite also forms secondary Ca-P hydroxyapatite and uranyl phosphate minerals, which also can serve as a driving force for the release of phosphate and calcium. However, the opposite phenomenon was noted in the experiments conducted for this study, where the release of $\mathrm{U}(\mathrm{VI})$ from synthetic autunite was slightly higher than $\mathrm{U}(\mathrm{VI})$ concentrations obtained in the experiments with natural autunite (Figure 1A and Figure 3A). Several factors could have contributed to such conflicting results. Gudavalli et al. (2013b) ran autunite dissolution experiments via a single pass flow through (SPFT) apparatus designed to limit the accumulation of reaction products in the reactor. This experimentation was conducted in batch bioreactors that were agitated at $100 \mathrm{rpm}$ in the incubator-shaker over more than 30 days. This leaves the possibility of the accumulation or precipitation in the bioreactors of secondary solid phases predicted by speciation modeling (Table 1 and Table 2). The formation of secondary uranyl-phosphate and calcium-phosphate mineral phases on the surface of the mineral can ultimately reduce the natural Ca-autunite mineral contact area, which bacterial cells can access. It thereby reduces the concentration of uranium released into the solution and detectable via the KPA instrument. The dissolution of synthetic Na-autunite produces only uranyl-phosphate secondary phases. 


\subsubsection{The effect of bacterial tolerance to uranium on autunite biodissolution}

In an assessment of the resistance of Hanford Site Arthrobacter isolates to uranium (VI) exposure (Katsenovich et al., 2012 b), the Arthrobacter G968 bacterial strain proved to remain viable in the presence of $0.5 \mathrm{ppm}$ of $\mathrm{U}(\mathrm{VI})$. After a week, the number of viable colonies was comparable to the control without U (VI). The increase in U(VI) concentration in the media solution highly inhibited G968 cell viability and no growth was noted on petri dishes after cell incubation for $24 \mathrm{~h}$ in the media amended with $9.5 \mathrm{ppm}$ of U(VI) (Katsenovich et al., $2012 \mathrm{~b}$ ). In contrast, a series of tests illustrated that Arthrobacter G975 exhibited a higher tolerance towards $\mathrm{U}(\mathrm{VI})$ relative to $\mathrm{G} 968$ and remained viable in the presence of $9.5-19 \mathrm{ppm}$ of $\mathrm{U}(\mathrm{VI})($ Katsenovich et al., $2012 \mathrm{~b})$. In order to see the changes on the bacterial surface at the nanoscale, AFM analysis was performed and results showed an unusually irregular and wrinkled surface on the G975 bacterial cell. Although precipitate was present on both Arthrobacter strains, the amount aggregated on the irregular surface of G975 surpassed the G968. The surface morphology of G975 strain supports a higher accessibility for the formation of the uranium precipitates. Experiments suggested that despite differences in surface morphology and tolerance to U(VI) between the two bacterial strains, G975 and G968, uranium biorelease from autunite minerals in the presence of bicarbonate ions in both cases was noted at the same capacity. The effect of both bacterial strains on autunite biodissolution decreases as the concentration of bicarbonate increases while the increase in soluble U (VI) concentration induced by bacterial strains is diminished, for larger $\left[\mathrm{HCO}_{3}{ }^{-}\right]$(Katsenovich et al, 2012a).

\subsection{Imaging Analyses}

The main goal of microscopy analysis was to qualitatively characterize autunite mineral surface composition and evaluate changes in the surface morphology in bicarbonate- bearing media 
inoculated with bacteria Arthrobacter strain G968. Figure 4 illustrates the bacterial attachment to the surface of the radioactive natural autunite mineral. After the reactors are inoculated, the cells are present in the liquid media as a suspension. Bacteria colonization of solid surfaces leads to the cells adhesion when bacteria are deposited on the solid surface via special cell surface structures, fibrils, forming links between the cell and the solid surface (van Loosdrecht et al., 1990). As a result of the breakdown of media organic compounds, bacterial cells release protons, organic acids and metabolites into the media solution (Francis, 2000; Knox, et al. 2008). The literature data on the influence of solid surfaces on microbial behavior demonstrate that the proton concentration at the surface is different from the bulk solution. The presence of a solid surface would hinder diffusion of protons away from the bacterium, and as a consequence, adsorbed cells are surrounded by a higher concentration of hydrogen ions as compared with the bulk liquid (Ellwood et al., 1982; Hattori and Hattori, 1963). As previously described, bacteria may lower the $\mathrm{pH}$ in the vicinity of the solid surface, thereby promoting release of uranium from the mineral surface. This is consistent with previous research that uranium release from autunite mineral is increased as the $\mathrm{pH}$ decreases (Wellman et al., 2007). The bacterial activities coupled with U(VI) complexation with bicarbonate contribute to the biodissolution of autunite minerals. SEM/EDS analysis of secondary minerals and biofilm created by Arthrobacter strain G968 on natural autunite surface help to distinguish between the elemental composition of the autunite surface and secondary minerals that may have been formed throughout the experiment. The atomic percentage of uranium on the autunite surface is higher, detected at around $50 \%$ (Figure $5 \mathrm{~A})$; whereas, the atomic percentage of uranium on the bacterial surface is much less, at around 0.9-1.7\% (Figure 5B). The composition of bacterial cell surfaces also features an elevated content of carbon and nitrogen ranging between $67-71 \%$ and 9.4-12.9\%, respectively. Further 
observations using microscopy revealed what would occur to the autunite mineral surface when exposed to bicarbonate- bearing media inoculated with bacterial cells of A.G968. Figure 5A illustrates this phenomenon, showing an accumulation of secondary phases that covers the surface of the mineral, obstructing active sites. Some bacteria appeared to be encrusted in secondary minerals, showing slightly lower weight percentages of carbon, phosphorus and nitrogen as $56-63 \%, 1.3-1.7 \%$, and $6.9-7.9 \%$, respectively, compared to the composition of the bacterial surface. Based on the obtained results, we can hypothesize that a mixture of secondary phases encrusted with bacteria might reduce bacterial access to active sites on the mineral. Alternatively, uranium released during mineral dissolution might not diffuse through the mixture of secondary phases and encrusted bacteria.This study provides a better understanding of the role of indigenous soil bacteria on the stability of autunite precipitates created as a result of the tripolyphosphate remediation technology and investigates the microbial effect on the uranium release from autunite solid phases in bicarbonate rich environments. It can be concluded that the low uranium tolerant strain, Arthrobacter strain G968 can accelerate the release of uranium from autunite in the presence of bicarbonate through biodissolution of both natural Ca-autunite and synthetic Na-autunite, in conditions mimicking arid and semiarid subsurface environments of the western U.S. The results of the study provide important insights into key biochemical factors affecting the environmental fate and transport of uranium.

\section{Acknowledgment}

Funding for this research was provided by U.S. DOE grant number DE-EM0000598. We would like to thank Dr. Patricia Sobecky and Dr. Robert J. Martinez from the Univ. of Alabama, Tuscaloosa, AL, for providing us with the Arthrobacter sp. strains and to acknowledge Robert Lapierre, DOE Fellow from the FIU Chemistry Department, and Tom Beasley from the FIU 
FCAEM for their assistance with the SEM/EDS analysis. We are grateful to Dr. Brady Lee of Pacific Northwest National Laboratory (PNNL) for reviewing the manuscript and providing valuable comments and suggestions.

\section{References}

Araujo JC, Téran FC, Oliveira RA, Nour EAA., Montenegro MAP, Campos JR, Vazoller RF, 2003. Comparison of hexamethyldisilazane and critical point drying treatments for SEM analysis of anaerobic biofilms and granular sludge. Journal of Electron Microscop, 52(4), 429-433.

Arcand, M.M., Schneider, K.D., 2006. Plant- and microbial-based mechanisms to improve the agronomic effectiveness of phosphate rock: a review. Anais da Academia Brasileira de Ciências 78 (4), 791-80

Balkwill DL, Reeves RH, Drake GR, Reeves JY, Crocker FH, King MB, Boone a. DR, 1997. Phylogenetic characterization of bacteria in the subsurface microbial culture collection. FEMS microbiology reviews, 20, 201-216.

Bernhard G, Geipel G, Reich T, Brendler V, Amayri S, Nitsche H, 2001. Uranyl (VI) carbonate complex formation: validation of the Ca2UO2(CO3)3(aq.) species. Radiochim. Act, 89, 511-518.

Beazly MJ, Martinez RJ, Sobecky PA, Webb SM, Taillefert M, 2007. Uranium biomineralization as a result of bacterial phosphatase activity: insights from bacterial isolates from a contaminated subsurface. Environ Sci. Technol., 4, 5701-5707

Behera, BC., Singdevsachan, SK., Mishra, RR., Dutta, SK., Thatoi, H.N., 2014. Diversity, mechanism and biotechnology of phosphate solubilising microorganism in mangrove-A review. Biocatal Agric Biotechnol., 3, 2, 97-110.

Boylen CW, 1973. Survival of Arthrobacter crystallopoietes during prolonged periods of extreme desiccation. Journal of Bacteriology, 113, 33.

Clark DL, Hobart DE, Neu MP, 1995. Actinide carbonate complexes and their importance in actinide environmental chemistry. Chem. Rev. 95, 25-48. 
Crocker FH, Fredrickson JK, White DC, Ringelberg DB, Balkwill, DL, 2000. Phylogenetic and physiological diversity of Arthrobacter strains isolated from unconsolidated subsurface sediments. Microbiology, 146, 1295.

Davis JA, 2001. Surface complexation modeling of uranium (VI) adsorption on natural mineral assemblages. Report NUREG/CR- 6708. Rockville, MD: U. S. Nuclear Regulatory Commission.

Ellwood DC, Keevil CW, Marsh PD, Brown CM, Wardell JN, 1982. Surface-associated growth. Philos. Trans. R. Soc. London Ser. B 297, 517-532.

Fratesi SE, Lynch FL, Kirkland BL, Brown LR, 2004. Effects of SEM preparation techniques on the appearance of bacteria and biofilms in the carter sandstone. Journal of Sedimentary Research, 74(6), 858-867.

Francis AJ, 2000. Microbial transformations of plutonium and implications for its mobility. Plut. Env. 1, 201-219

Fredrickson JK, Zachara JM, Balkwill D L, Kennedy D, Li SW, Kostandarithes HM, Daly MJ, Romine MF and Brockman FJ, 2004. Geomicrobiology of high-level nuclear wastecontaminated vadose sediments at the Hanford Site, Washington State. Appl. Environ. Microbiol. 70, 4230.

Giammar D, 2001. Geochemistry of uranium at mineral-water interfaces: rates of sorptiondesorption and dissolution-precipitation reactions. Dissertation (Ph.D.), California Institute of Technology. http://resolver.caltech.edu/CaltechETD:etd-05212002-125705

Grenthe I, Fuger J, Konings RJM, Lemire RJ, Muller AJ, Nguyen-Trung C, Wanner H, 1992. Chemical Thermodynamics of Uranium. New York: Elsevier.

Gorman-Lewis D, Burns PC, Fein JB, 2008. Review of uranyl mineral solubility measurements. J. Chem. Thermodynamics 40, 335-352.

Gorman - Lewis D, Shvareva T, Kubatko K, Burns P, Wellman DM, Amara B, Szymanowski JS, Navrotsky A, Fein J B, 2009. Thermodynamic properties of autunite, uranyl hydrogen phosphate, and uranyl orthophosphate from solubility and calorimetric measurements. Environ. Sci. Technol. 43, 7416-7422.

Gudavalli R, Katsenovich Y, Wellman D, Lagos L, Tansel B, 2013a. Quantification of kinetic rate law paramters for the dissolution of sodium meta-autunite as a function of aqueous bicarbonate concentration. Environmental Chemistry, 10(6), 475-485. 
Gudavalli R, Katsenovich Y, Wellman D., Idarraga M, Lagos L, Tansel, B, 2013 b. Comparison of the kinetic rate law parameters for the dissolution of natural and synthetic autunite in the presence of aqueous bicarbonate ions. Chemical Geology, 351, 299-309.

Hattori R, Hattori T, 1963. The effect of a liquid-solid interface on the life of microorganisms. Ecol. Rev. 16, 63-70.

Kalmykov SN, Choppin GR, 2000. Mixed $\mathrm{Ca}^{2+} / \mathrm{UO}_{2}{ }^{2+} / \mathrm{CO}_{3}{ }^{2-}$ complex formation at different ionic strengths, Radiochim. Acta, 88, 603.

Katsenovich Y, Carvajal D, Wellman D, Lagos L, 2012a. Enhanced U (VI) release from autunite mineral by aerobic Arthrobacter sp. in the presence of aqueous bicarbonate.

Chemical Geology, 308-309, 1-9.

Katsenovich Y, Carvajal D, Guduru R, Lagos L, 2012b. Assessment of the Resistance to Uranium (VI) Exposure by Arthrobacter sp. Isolated from Hanford Site soil. Geomicrobiology Journal.

Knox A, Brimon R, Kaplan D, Paller M, 2008. Sci Total Environ, 395(63).

Langmuir D, 1978. Uranium solution- mineral equilibria at low temperatures with application to sedimentary ore deposits. Geochimica et Cosmochimica Acta, 42, 547-569.

Liu C, Jeon BH, Zachara JM, Wang Z, Donhalkova A, Fredrickson JK, 2006. Kinetics of microbial reduction of solid phase U(VI). Environ. Sci Technology, 40(20), 6290-6296.

Lloyd RJ and Renshaw CJ, 2005. Bioremediation of radioactive waste: radionuclide-microbe interactions in laboratory and field-scale studies. Cur. Opi. Biotech., 16(3), 254-260

Nedelkova M, Merroun ML, Rossberg A, Hennig C, Selenska-Pobell S, 2007. Microbacterium isolates from the vicinity of a radioactivewaste depository and their interactions with uranium. FEMS Microbiol Ecol, 59(3), 694-705, 12 
Sepúlveda P, Katsenovich Y, Lagos L, 2013. Investigation on Microbial Dissolution of Uranium (VI) from Autunite Mineral. In the proceedings of the Waste Management Symposia, Feb 24-28, Phoenix, AZ, U.S.

Sowder AG, Clark SB, \& Fjeld RA, 2001. The impact of mineralogy in the U(VI)-CaPO4 system on the environmental availability of uranium. J Radioanal Nucl Ch, 248(3), $517-524$

Smeaton CM, Weisener CG, Burns PC, Fryer BJ, Fowle DA, 2008. Bacterially enhanced dissolution of meta-autunite. Am. Mineral. 93, 1858-1864.

Sparks DL, 1999. Kinetic and mechanisms of soil chemical reactions at the soil mineral/water interface. In: Sparks, DL (Ed), Soil Physical Chemistry.

Van Loosdrecht MC, Lyklema J, Norde W, Zehnder AJ, 1990. Influence of interfaces on microbial activity. Microbiol. Rev. 54(1), 75.

Van Waasbergen LG, Balkwill DL, Crocker FH, Bjornstad BN, Miller RV, 2000. Genetic diversity among Arthrobacter species collected across a heterogeneous series of terrestrial deep-subsurface sediments as determined on the basis of 16S rRNA and recA gene sequences. Appl. Environ. Microbiol., 66, 3454.

Vazques P, Holguin G, Puente ME, Lopez-Cortes A, Bashan Y, 2000. Phosphatesolubilizing microorganisms associated with the rhizosphere of mangroves in a semiarid coastal lagoon. Biol. Fertil. Soil, 460-468.

Wellman DM, Catalano JG, Icenhower JP, Gamerdinger AP, 2005. Synthesis and characterization of sodium meta-autunite, $\mathrm{Na}\left[\mathrm{UO}_{2} \mathrm{PO}_{4}\right] \cdot 3 \mathrm{H}_{2} \mathrm{O}$. Radiochimica Acta, 93, 393 399.

Wellman DM, Icenhower JP, Gamerdinger A, Forrester SW, 2006. Effects of pH, temperature, and aqueous organic material on the dissolution kinetics of meta-autunite minerals, (Na, Ca)2-1[(UO2)(PO4)]2·3H2O. American Mineralogist, 91(1), 143-158.

Wellman DM, Gunderson KM, Icenhower JP, Forrester SW, 2007. Dissolution kinetics of synthetic and natural meta-autunite minerals, $\mathrm{X}^{\wedge}\left((\mathrm{n})+\_3-\mathrm{n}[(\mathrm{UO} 2)(\mathrm{PO} 4)] 2 \mathrm{xH2O}\right.$, under acidic conditions. Geochemistry Geophysics Geosystems: An electronic journal of the earth sciences, 8(11), 1-16. 
Zachara JM, Serne J, Freshley M, Mann F, Anderson F, Wood M, Jones T, Myers D, 2007. Vadose Zone J. 6, 985-1003. 
Figure 1. A) Changes for aqueous U (VI) concentrations as a function of time for the natural autunite dissolution experiments inoculated with Arthrobacter G968 strain (n=3). B) Aqueous phosphorus release as a function of time from the natural autunite dissolution experiments inoculated with Arthrobacter G968 strain. C) Aqueous Ca release as a function of time for the biotic reactors inoculated with Arthrobacter G968 strain. Red arrow indicates time of bioreactors inoculation with G968.

Figure 2. Changes for aqueous $\mathrm{U}(\mathrm{VI})$ as a function of time for the non-contact natural autunite dissolution insert experiments inoculated with Arthrobacter G968 strain. Red arrow indicates time of bioreactors inoculation with G968.

Figure 3. A) Changes for aqueous U (VI) as a function of time for the synthetic autunite dissolution experiments inoculated with Arthrobacter G968 strain. Red arrow indicates time of bioreactors inoculation with G968. B) Aqueous phosphorus release as a function of time from the synthetic autunite dissolution experiments inoculated with Arthrobacter G968 strain. C) Aqueous Na release as a function of time from the synthetic autunite dissolution experiments inoculated with Arthrobacter G968 strain. Red arrow indicates time of bioreactors inoculation with G968.

Figure 4. SEM images of G968 grown on autunite surface in the presence of $\mathrm{HCO}_{3}{ }^{-}$. Clearly illustrating individual bacteria are deposited on the solid surface via special cell surface structures, fibrils; A) Natural autunite, $3 \mathrm{mM} \mathrm{HCO}_{3}$. B) Synthetic autunite, $10 \mathrm{mMHCO}_{3}$ white arrow shows G968 cells attached to the surface.

Figure 5. SEM/EDS analysis of secondary minerals and biofilm created by G968 strain on natural autunite surface and compositional analysis (\% weight) for each point at A) $5 \mathrm{mM} \mathrm{HCO}_{3}$; B) $10 \mathrm{mM} \mathrm{HCO}_{3}$ 

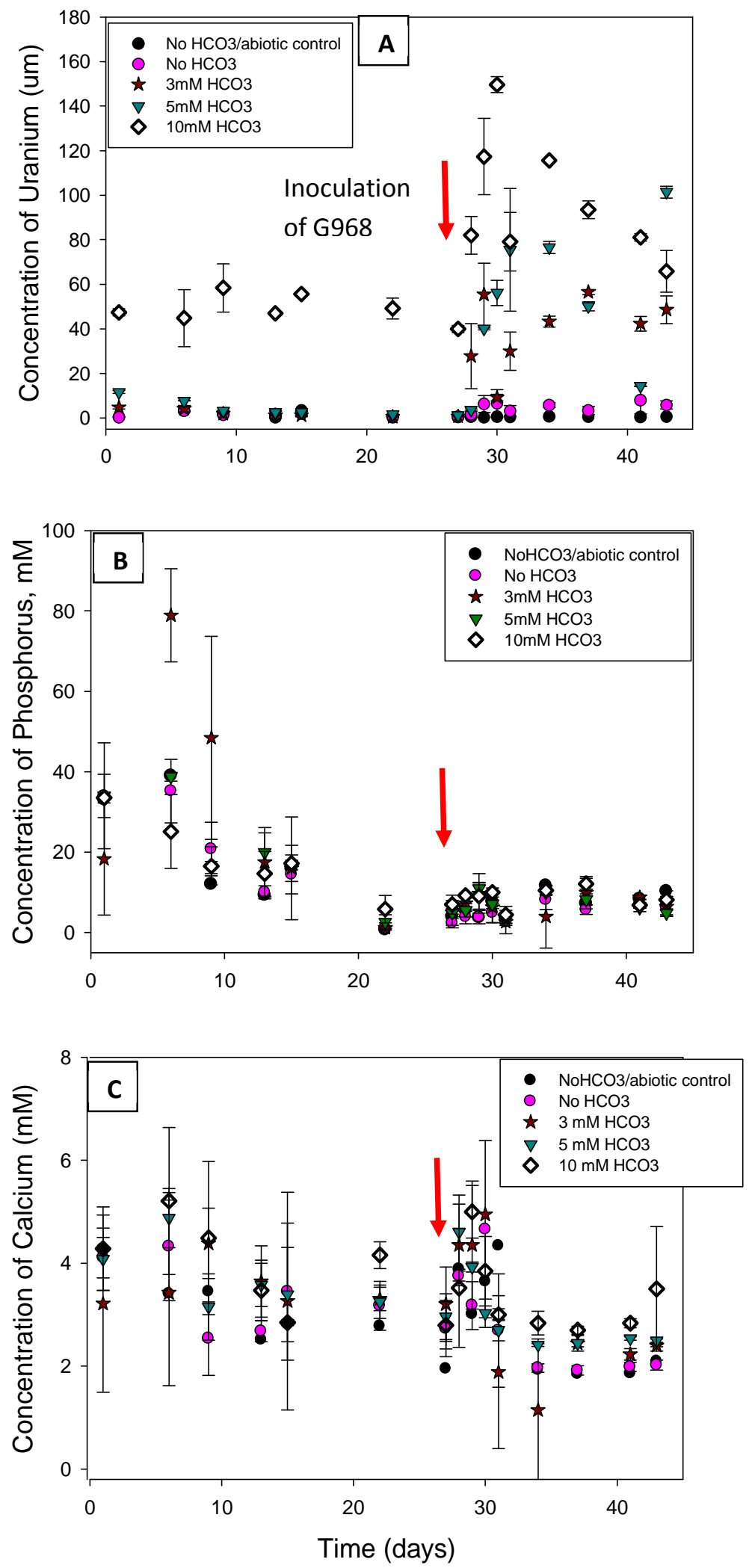


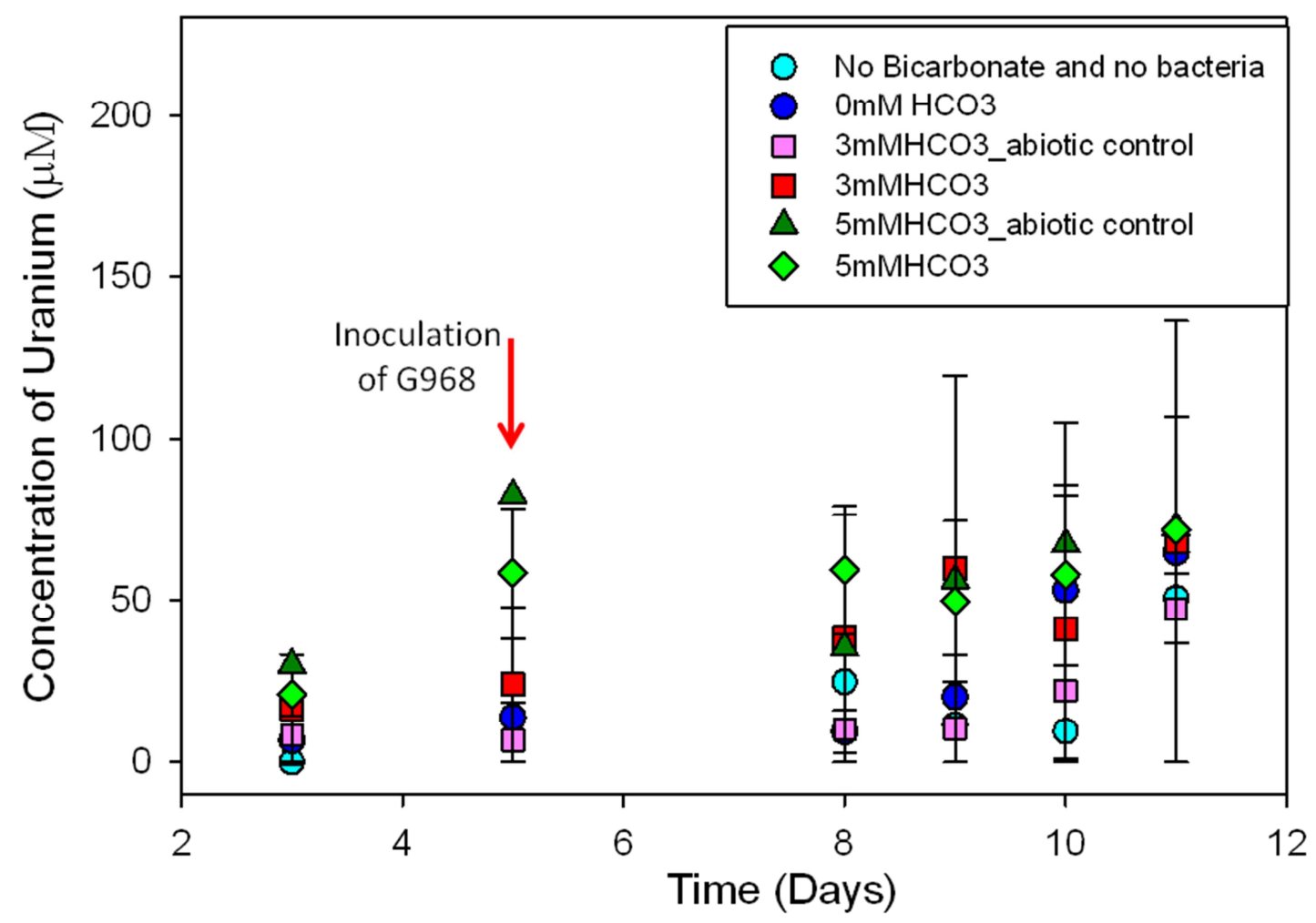



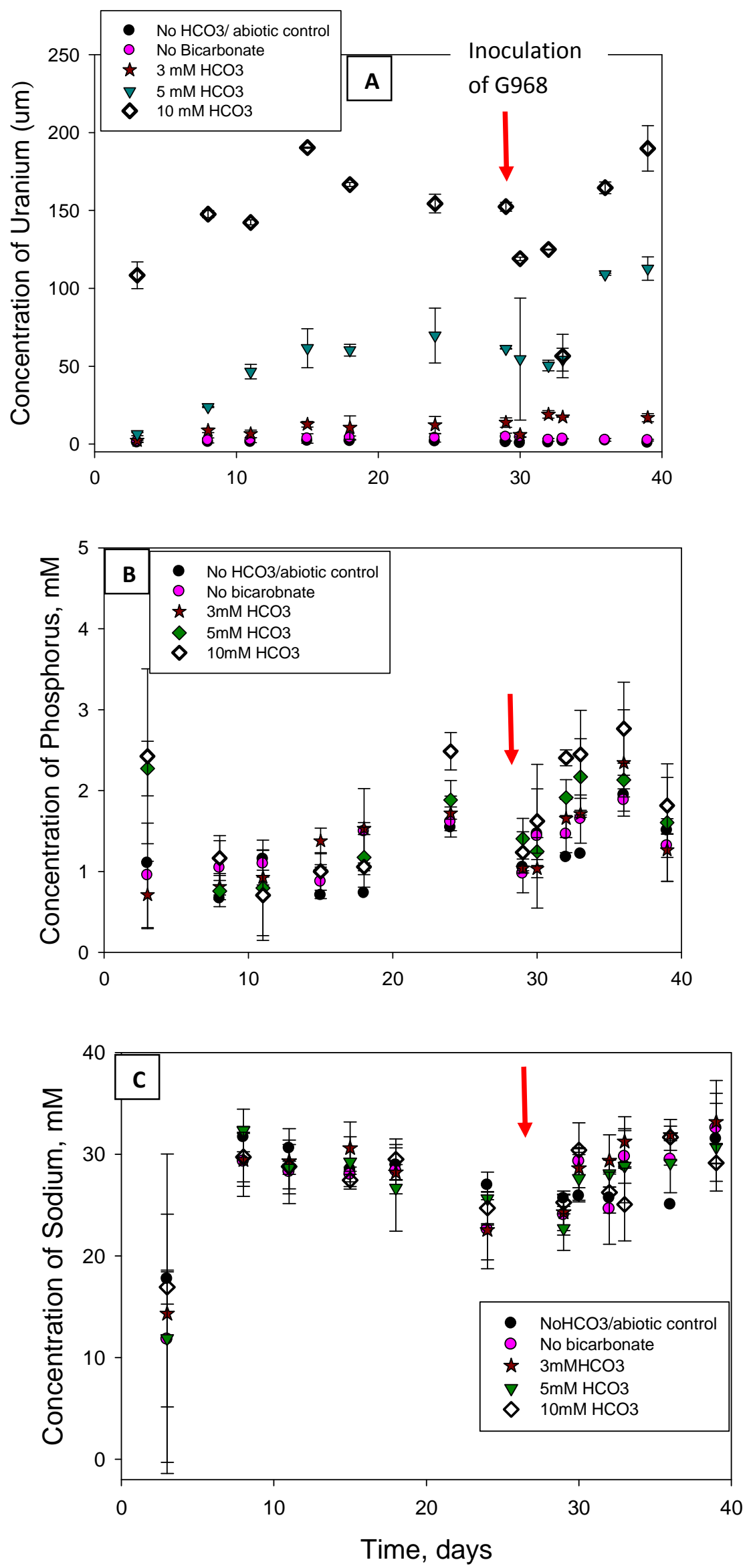


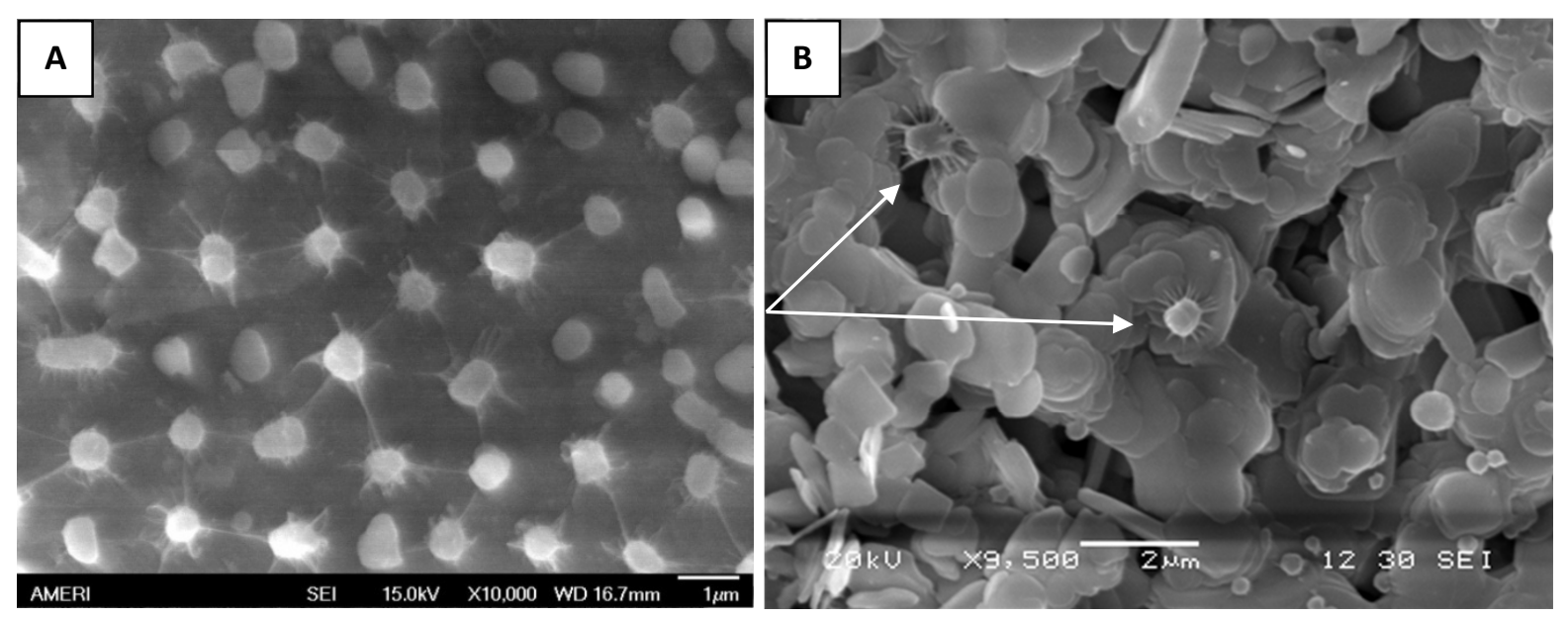




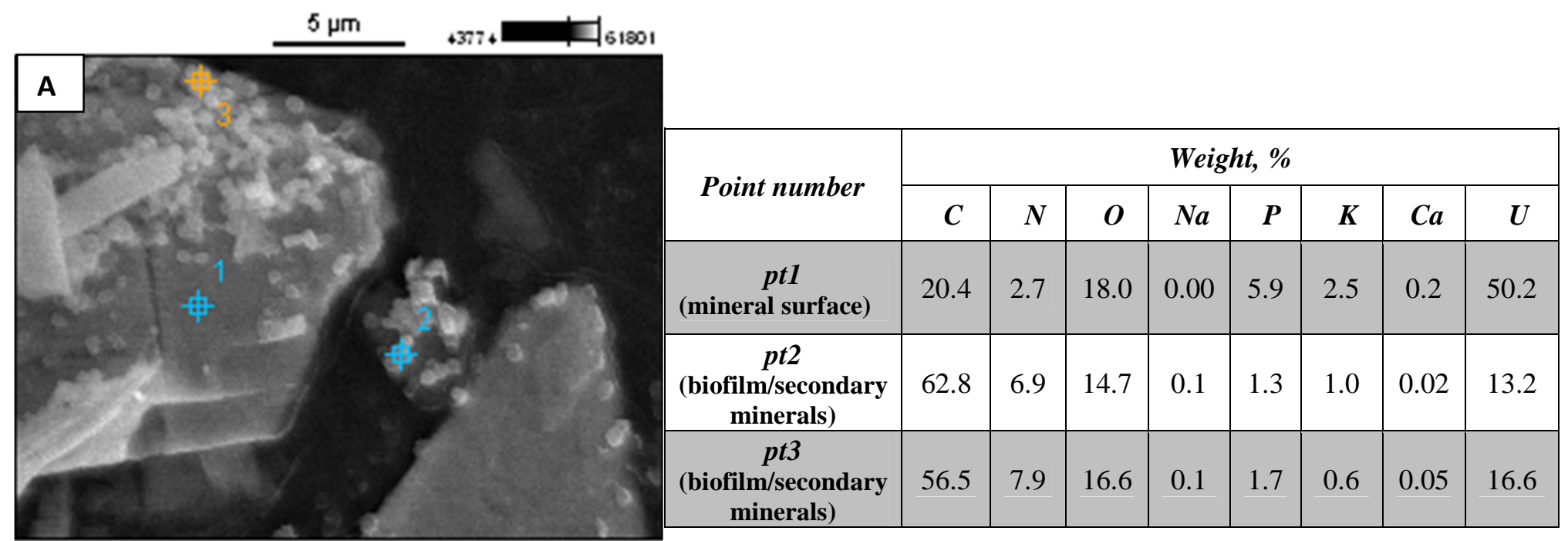

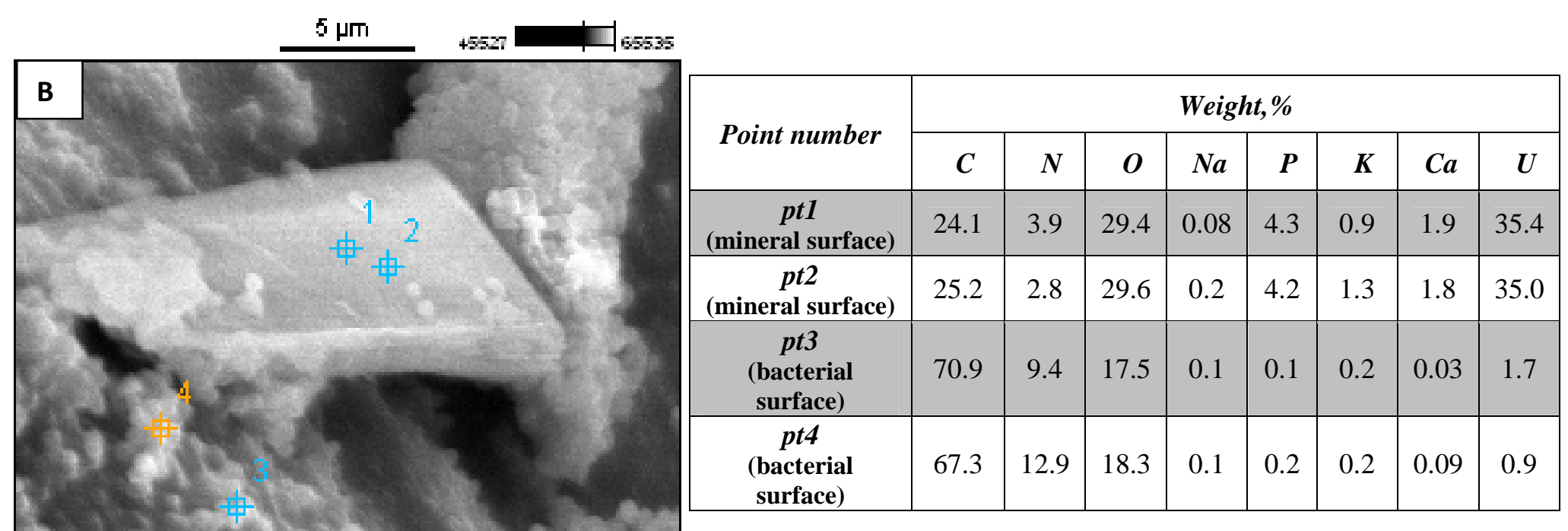


1. Low-tolerant G968 Arthrobacter strain accelerates U(VI) release from autunite in the presence of $\left[\mathrm{HCO}_{3}{ }^{-}\right]$

2. The effect of bacteria on autunite dissolution is reduced as the concentration of $\left[\mathrm{HCO}_{3}{ }^{-}\right]$ increases

3. The U(VI) release from natural Ca-autunite is lower than from synthetic Na- autunite

4. A direct interaction between bacteria and mineral is not necessary to result in U(VI) release from autunite 